\title{
THE INFLUENCE OF FORMAL AND INFORMAL COMMUNICATION IN SOCIAL MEDIA ON GENERATION Y ONLINE PURCHASE INTENTIONS
}

\author{
Y. S. Lim*, T. H. Ng, S. F. Yeo, Y. H. Kerk \\ Faculty of Business, Multimedia University, 75450 Bukit Beruang, Melaka, Malaysia \\ *Corresponding author: lim.ying.san@mmu.edu.my
}

\begin{abstract}
The objective of this study is to determine how the formal and informal communication in social media can be used to affect the Generation Y online purchase intention. Generation Y is selected in this study as this generation is the generation who are heavily depend on social media. Selfadministrated questionnaire is used to gather the respond from the target respondent by using random sampling. The result from the sample size of 230 Generation Y respondents showed that there is positive influence of online sales promotion and word of mouth on the consumers purchase intention. The outcome of this study is very important to give an insights to the business on how they should use the social media to communicate and influence the consumer online purchase intentions.
\end{abstract}

\section{Keywords: Social Media, Generation Y, Online Purchase Intention}

\section{INTRODUCTION}

The advancement in technology make Internet become inseparable with people daily life. In year 2017, the number of worldwide internet users was reached 37 billion (Internet World Stats, 2017). In conjunction with the adoption of Internet, the social media become one of the most popular online activities today. According to The Statistics Portal (2017), there were around 1.33 billion consumers visited the social media daily. This trend created many opportunities to the business people to incorporated internet and social media in their business activities. Those activities include communicating to the consumers and to conduct the online shopping activity.

Today, social media become one of the important communication tools in the business market, either as a formal or informally. Formal communication means the communication messages passing officially from the organization. The example of formal communication are through advertisement, personal selling, sales promotion, public relation and direct marketing. Informal communication means the communication is based on the relationship among peoples (Schiffman \& Wisenblit, 2015). According to Evans and McKee (2010), social media enable the marketers to have a formal communication with customer by informing consumers on the marketing information and to retain the brand's existence in the Internet. Similarly, social media also become consumers' informal communication to communicate and to seek for product advice from with others users. Due to these, social media had become an important market intelligence tools as marketers begin to understand how important consumers use social media to gain insight about certain brands (Rockendorf, 2011).

There was getting more and more online sellers involve themselves in social media to sell the products. Some of the things that online sellers did on social media were online advertising and sale promotion in order to encourage consumers to make purchase. Online advertising means that the advertisements were convey to users through electronic information services (Hawkins, 1994). Too much advertising will make consumers felt annoyed when they are browsing the internet. This will makes consumer have a doubt on the credibility of the advertising and have a strong tendency toward advertising avoidance (Shavitt et al., 1998). In addition, according to Odunlami and Ogunsiji (2011), sales promotion was the main determinant of consumer's online shopping behavior. Due to the limitation of online environment. In online setting, consumers unable to feel and touch the 
products before purchasing was made. There were issues of privacy, shipping costs and intangibility of the products which affected the consumers' confidence with online shopping. This makes online sales promotion become one of the important cue to move the consumer to purchase a products online as the sales promotion can reduce the purchase risk upon purchase.

The limitation of online environment where the consumer cannot see and touch the product before they purchase create some concern on the consumer before they purchase a products. When consumers went to purchase products from online shopping, they wish to have a positive, trustworthy and honest evaluation about products. Word-of-mouth will the customers purchase intention. Word-of-mouth had become more popular with used of social networking tools such as Facebook, Twitter and MySpace. However, it was easier for consumer to spread negative word-ofmouth online. Negative word-of-mouth will severely damage or even destroy a business. When consumers see the negative WOM about the company, they will tend to shift to their competitors (Bone, 1995). In contrast, when online sellers post the information similar to consumer's value, then they will choose to trust the online sellers in order to spread the positive word-of-mouth. The positive information share by sellers was helping company to do viral marketing. Positive word of mouth used to level up consumer's purchase intentions for products that are innovative by cutting down the hazard (Dichter, 1966), help promote favorable image of the brand and the company (Arndt, 1967).

Based on the issues discussed above, the problem statement of this research is how's the influence of formal and informal communications in social media on generation Y's purchase intention. The objective of the research was to identify how online advertising and online sales promotion in formal communication, and world of mouth in informal marketing communication in social media influence customers purchase intention.

The research will benefits the marketers who targeted the Generation $Y$ by helping them to design a proper strategy to influence the Generation Y purchase intention online. In addition, this study identify the important of communication in social media in influencing the consume purchase intention. It is very important now as most of the Generation Y are attached to social media nowadays and they even trust social media more compared to traditional media. Hence, this study will fill in the knowledge gap seeing how the effect of social media in affecting the generation Y purchase intention.

\section{LITERATURE REVIEW \\ Communication in Marketing}

Communication in Marketing can be divided into formal communication and informal communication. The message in formal communication normally is send by using formal sources such as sales person or by using a proper promotional marketing tools such as advertisement, sales promotions. On the other hand, informal communication is the communication that happened within the informal source such as with peers either face to face or via electronics devices (Schiffman \& Wisenblit, 2015).

\section{Online Sales Promotion}

Online sales promotion is define as the inducements used by the marketers to motivate target customers and to speed up their buying intention to the specific products or services online (Pathak et al., 2010). The tools used by the marketers include online coupon, online price discount, buy one free one and so on. Compare to promotion activities offline, online sales promotion was more cost-efficient and widely used by the consumers (Lamb et al., 2009). Percy and Elliott (2009) suggested that companies is encouraged to use consumer sales promotion on their websites to get attention from customers and motivate them to purchase their products. Also, according to Fill (2007), online sales promotion was used by companies to build a brand's interest among customers.

\section{Online Advertisement}

Online advertisements can defined as advertisements that were delivered to users by using electronic information services (Hawkins, 1994). According to Taylor et al. (2011), online advertising consists 
of either videos or banner advertising. Recently, online advertising such as Facebook is the new challenges to marketers. According to Neslin (2012) and Tassi (2013), there were over one million advertisers spent $\$ 2.75$ billion on Facebook, it reflecting a confidence by advertisers that Facebook will deliver their messages to target audience effectively (Tan \& Piron, 2002). The concept of social networking sites which allowed users to share their ideas and interacting with others, created a good fit for marketers to use advertisement to interact and communicate with potential customers.

\section{Online Word of Mouth}

Word-of-mouth in social media means network users exchange the information and conducting discussions on some products or services in the internet (Sun et al., 2006). Social media allowed internet users to establish contents about anything which consist of organizations, products and brands (Kaplan \& Haenlein, 2012). According to Goldenberg et al. (2001) and Goldenberg (2007), social network platforms nurture the interchange of WOM messages by creating a virtual community for consumers to interact with one another. Mangold and Faulds (2009) also indicates that social media created a platform for variety of online information-sharing. This include social networking sites (e.g. Facebook and MySpace), creativity work-sharing sites (e.g. Youtube) and micro blogging sites (e.g. Twitter) (Kelly et al., 2010). It was allows users to spread word-ofmouth through social media. Online word-of-mouth was an important element of online shopping, positively perceived by customers and influenced customer behavior. Online word-of-mouth help to establish consumers' brand awareness and influence consumers' brand loyalty (Yang, 2013). Online word-of-mouth had influence on consumer's purchase intentions because consumer, especially Generation Y heavily rely on online word-of-mouth before they make purchase decisions (Doh \& Hwang, 2009). Online word-of-mouth is one of the important messages in purchasing behavior and it will influence the relationship between the consumers with community, promotion activities, reputation and image of firms.

\section{Purchase Intention}

Purchase intention means that consumer's subjective judgment is reflected after general evaluation to purchase products and services. Purchase intention represents what consumer think and what will buy in their mind in the future (Blackwell et al., 2001). Purchase intention indicates that consumers will follow their need recognition, information search through external environment, evaluation of alternatives to make purchase decision and post-purchase experience. When the purchase intention is high, consumers was more likely to purchase a product (Schiffman \& Kanuk, 2000).

\section{Generation Y}

Generation Y came after Generation X and also known as millennials. Generation Y can generally defined as those whose birth years fall between 1980 and 1994 (McCrindle, 2006). Generation Y are the first global generation connected with internet and social media (Espinoza et al., 2010), they cannot live without internet, they are online 24/7 and 365 days a year. This generation prefers communicated to others through email and text message rather than actual face to face communication because they was highly educated and technology-savvy. Generation $\mathrm{Y}$ had a higher purchasing power compare to others generations.

\section{Research Framework}

Online sales promotion is the activities that use some inducements to induce the target consumers to speed up their buying intention to the specific products and services [31]. Online sales promotion will encourage buyers to purchase products promptly, by lowering prices to add value. Online sales promotion tool such as coupons, price reductions and free gift will attracted consumer attention and lead them to buy the products fast. Hence, the research hypothesis stating this is:

H1: Sales promotion in social media has a positive relationship with Generation Y's purchase intention.

According to Arens (1996), people get the information from advertisement through the attractiveness it holds, the attention it build and the awareness it gives. Advertising not only provided information about products and services, but it also active attempt at influencing consumers to 
action. The effective advertising will lead consumers to make purchase intention. Hence, the research hypothesis stating this is:

$\mathrm{H} 2$ : Online advertising in social media has a positive relationship with generation Y's purchase intention.

Consumers were more believe about product information online post rather than other platform information when they want to make purchase. According to the previous studies (Barnes, 2010; Bickart \& Schindler, 2001), messages that discussed among the users in the Internet were more powerful than the marketer-generated information. Hence, the research hypothesis stating this is:

H3: Word-of-mouth in social media has a positive relationship with generation Y's purchase intention.

Based on the discussion above, the research framework of the study is shown below.

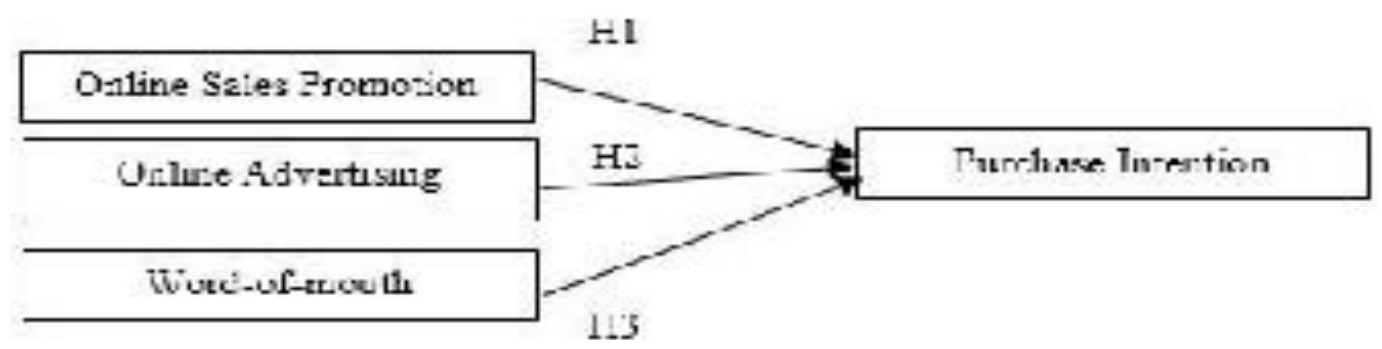

Figure 1. Research framework

\section{METHODOLOGY}

Questionnaires is used in this research in order to collect the data. This research target on Generation $\mathrm{Y}$ in Malaysia which age from 15-30 years old. Generation $\mathrm{Y}$ is chosen in this study because they are the first global generation connected with internet and social media (Espinoza et al., 2010). In addition, Generation Y spent aggressively and they are comfortable with on the internet (eMarketer, 2012).

Non-probability convenience sampling was used in the study to identify the respondents. Some screening questions were added in the questionnaire to identify the respondents before they answer the questions. There were 250 Generation Y respondents participated the questionnaires.

The instrument in the questionnaire were adopted from the previous study. Instrument for Purchase intention were adopted from Jarvenpaa et al. (1999), online sales promotion from Yin-Fah et al. (2011), online advertising from (Chang \& Thornson, 2004; Holbrook \& Batra, 1987) and world of mouth from (Goyette et al., 2010).

\section{RESULTS AND DATA ANALYSIS \\ Respondent Profile}

In this research, 230 usable data were collected from Generation Y. Among all the respondents, 46\% of the respondent are male and the rest are female. All the respondents have online purchase experience via Facebook before in the past 6 months. More than $90 \%$ of the respondents spent more than 1 hour in the internet everyday. The frequency analysis showed that the products most purchase by generation $\mathrm{Y}$ through social media were clothing, cosmetic, jewelry and books.

\section{Reliability Test}

The reliability test of the study showed that the Cronbach's Alpha for purchase intention is 0.64, online sales promotion is 0.64 , online advertising is 0.73 and word of mouth is 0.76 . The reliability result of the study showed that all the variables are reliable as the Cronbach's Alpha for the variables are more than 0.6 (Sekaran \& Bougie, 2016).

\section{Correlation Analysis}

Table 1 shows the result of the correlation analysis: 
Table 1. Correlations

\begin{tabular}{|c|c|c|}
\hline & & Purchase Intention \\
\hline Online Sales Promotion & Pearson Correlation & 0.44 \\
\cline { 2 - 3 } & Sig. (2-tailed) & 0.000 \\
\hline \multirow{2}{*}{ Online Advertising } & Pearson Correlation & 0.33 \\
\cline { 2 - 3 } & Sig. (2-tailed) & 0.000 \\
\hline \multirow{2}{*}{ Word-of-Mouth } & Pearson Correlation & 0.38 \\
\cline { 2 - 3 } & Sig. (2-tailed) & 0.000 \\
\hline
\end{tabular}

The result of the study shows that here is significant correlation between online sales promotion and purchase intention as the p-value $<0.05$ and the value for Pearson Correlation of 0.44 which indicated that the relationship is moderate. The correlation for online advertising and purchase intention also significant because p-value $<0.05$ with the Pearson correlation of 0.33 indicated that there is a weak relationship between variables. Besides, word-of-mouth and purchase intention have significant correlation due to $\mathrm{p}$-value $<0.05$ and the Pearson Correlation value was 0.38 which means that there is also a weak relationship between variables.

\section{Multiple Linear Regression}

Multiple linear analysis is used to analyses the relationship between the variables and to test the hypothesis of the study. The result is shown in Table 2.

Table 2. Multiple linear regressions

\begin{tabular}{|c|c|c|c|c|c|}
\hline & \multicolumn{3}{|c|}{ Unstandardized Coefficients } & \multicolumn{2}{c|}{ Standardized Coefficients } \\
\hline & B & SE & Beta & t & Sig. \\
\hline (Constant) & 0.87 & 0.31 & 0.0 & 2.77 & 0.0006 \\
\hline Online sales promotion & 0.38 & 0.10 & 0.2 & 3.86 & 0.000 \\
\hline Online advertising & 0.09 & 0.07 & 0.0 & 1.22 & 0.225 \\
\hline Word of mouth & 0.21 & 0.07 & 0.2 & 3.22 & 0.001 \\
\hline
\end{tabular}

Dependent variable: Purchase intention

$\mathrm{R}^{2}=0.23, \mathrm{~F}=23.13$, sig. level of 0.000

Based on Table 2, the value for $\mathrm{R}$ square is 0.23 which means that in the independent variables can explain $23 \%$ of the variation in dependent variable. According to the ANOVA table, the F value is 23.13 and the p-value was 0.000 which was lower than 0.05 , so it was a significant relationship.

$\mathrm{P}$-value for online sales promotion is 0.000 which is less than 0.05 , this indicated hypothesis 1 is accepted. The $p$-value for online advertising which is 0.225 , it is lower than 0.05 so hypothesis 2 is not accepted. Lastly, the p-value for word-of-mouth is 0.001 which was lower than 0.05 , thus hypothesis 3 is accepted. While the p-value for online sales promotion is $0.38, \beta$ value for online advertising is 0.09 and $\beta$ value for word-of-mouth is 0.21 . This indicated that online sales promotion is the most influential factor in influencing consumer online purchase intention.

\section{Discussion}


The finding of the study shown that that online sales promotion have a positive relationship with purchase intention. According to Clow and Baack (2004), sales promotion offers in the online environment is very important to encourage consumer purchasing behavior. This result also consistent with the research conducted by Neslin (2002), which stated that online sales promotion had impact on the consumer's purchase intention and behavior. This happened because consumer normally will act faster in online compared to offline. In the online environment, the information search always come with purchase button beside. Thus, sales promotion can encourage the consumers to move to the purchase decision faster without much considerations. For example, an attractiveness online sales promotion such as price discount, buy one get one free and free gifts will make the consumers to act fast to purchase the products they like right after the information searching process without any delay. Hence, online retailers should aware of the important of online sales promotion in moving the consumers towards the purchase behavior. Online retailers should consider to offer more attractive sales promotion to encourage the consumers to have a prompt response after they search the products. Marketers are now bombarding consumers with various forms of advertisement online. Sometimes, consumers are forced to view the unwanted advertising even though they were unwilling and this will make them feel aggravating. Thus, they perceived online advertising was not the important factor to influence their purchase intention. Lastly, the findings of the research also supported that electronic word-of-mouth have a positive relationship with purchase intention. This result is consistent with the previous research, which also revealed that there is a positive relationship between electronic word-of-mouth and purchase intention as generation $\mathrm{Y}$ treat word-of-mouth as a more reliable course of communication compared to the advertisement. With this, online retailers must closely monitor the word-of- mouth of products and services that consumers spread to others. Online retailers also should fulfill consumer's needs and wants, provide quality products and services and manage well the reputation of the online business in order to obtain positive word-of-mouth. Buzz agent should be hired to do the viral marketing activities to the consumers in the cyberspace.

\section{CONCLUSION}

This study focus on the influence of formal and informal communication in social media in affecting the purchase intention of Generation Y. There were 230 sets of Questionnaires were collected from Generation $\mathrm{Y}$ who have experience in buying products via social media. The result of the study indicated that sales promotion and word-of mouth in social media will affect the purchase intention of Generation Y whilst online advertising will not. This study give an ideas to the online seller on how they can use online sales promotion and word-of-mouth to affect the customer and at the same time be aware when using online advertising.

\section{REFERENCES}

Arens, F. W. (1996). Contemporary advertising. McGraw-Hill Higher Education.

Arndt, J. (1967). Role of product-related conversations in the diffusion of a new product. Journal of Marketing Research, 4(3), 291-295.

Barnes, N. (2010). Tweeting and blogging to the top. Marketing Research, 22(1), 8-13.

Bickart, B., \& Schindler, R. M. (2001). Internet forums as influential sources of consumer information. Journal of Interactive Marketing, 15(3), 31-40.

Blackwell, R. D., Engel, J. F., Miniard, \& Paul, W. (2001). Consumer behavior. South-Western.

Bone, P. F. (1995). Word-of-mouth effects on short-term and long-term product judgments. Journal of Business Research, 32(3), 213-223.

Chang, Y., \& Thornson, E. (2004). Television and web advertising synergies. Journal of Advertising, 33(2), 75-84.

Clow, K. E., \& Baack, D. (2004). Integrated advertising, promotion and marketing communications. Pearson Prentice Hall.

Dichter, E. (1966). How word-of-mouth advertising works. Harvard Business Review, 44(6), 147-166.

Doh, S. J., \& Hwang, J. S. (2009). How consumers evaluate eWOM (electronic word-of-mouth) messages. Cyberpsychology and Behavior, 12(2), 193-197. 
eMarketer. (2012). Gen Y speeds up luxury goods spending flash sale sites and the fashion industry's maturing web presence boost sales to young consumers. https://www.emarketer.com/ Article/Gen-Y-Speeds-Up-Luxury-Goods-Spending/1008854

Espinoza, C., Ukleja, M., \& Rusch, C. (2010). Managing the millennials: Discover the core competencies for managing today's workforce. John Wiley and Sons.

Evans, D., \& McKee, J., (2010). Social media marketing: The next generation of business engagement. John Wiley and Sons.

Fill, C. (2007). Simply marketing communications. Pearson Education.

Goldenberg, B. (2007). The rise of the digital client. https://www.destinationcrm.com/Articles/ ReadArticle.aspx? ArticleID $=41751$.

Goldenberg, J., Libai, B., \& Muller, E. (2001). Talk of the network: A complex systems look at the underlying process of word-of-mouth. Marketing Letters, 12(3), 211-223.

Goyette, I., Ricard, L., Bergeron, J., \& Marticotte, F. (2010). e-WOM scale: Word-of-mouth measurement scale for e-services context. Canadian Journal of Administrative Sciences/Revue Canadienne des Sciences de l'Administration, 27(1), 5-23.

Hawkins, D. T. (1994). Electronic advertising on online information systems. Online, 18(2), 26-39.

Holbrook, M. B., \& Batra, R. (1987). Assessing the role of emotions as mediators of consumer responses to advertising. Journal of Consumer Research, 14(3), 404-420.

InternetWorld Stats. (2017). Internet users and population $s \quad t \quad a \quad t \quad i \quad s \quad t \quad i \quad c \quad s$. www.internetworldstats.com/stats 1.htm.

Jarvenpaa, S. L., Tractinsky, N., Saarinen, L., \& Vitale, M. (1999). Consumer trust in an internet store: A cross-cultural validation. Journal of Computer-Mediated Communication, 5(2), 1-33.

Kaplan, A. M., \& Haenlein, M. (2012). Social media: Back to the roots and back to the future. Journal of Systems and Information Technology, 14(2), 101-104.

Kelly, L., Kerr, G. \& Drennan, J. (2010). Avoidance of advertising in social networking sites: The teenage perspective. Journal of Interactive Advertising, 10(2), 16-27.

Lamb, C. W., Hair, J. F., \& McDaniel, C. (2009). Essentials of marketing. South-Western Cengage Learning.

Mangold, W. G., \& Faulds, D. J. (2009). Social media: The new hybrid element of the promotion mix. Business Horizons, 52(4), 357-365.

McCrindle, M. (2006). New generations at work: Attracting, recruiting, retaining and training generation Y-The ABC of XYZ. McCrindle Research Pty Ltd.

Neslin, S. A. (2002). Sales promotion. Marketing Science Institute.

Neslin, S. A. (2012). Nielsen Australia online landscape review. http://www.nielsen.com/content/

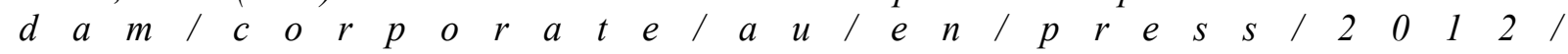
Nielsen\%20Online\%20Landscape\%20Review\%20August\%202012\%20Media\%20Pack.pdf.

Odunlami, I. B., \& Ogunsiji, A. (2011). Effect of sales promotion as a tool on organizational performance. Journal of Emerging Trends in Economics and Management Sciences, 2(1), 9-13.

Pathak, B., Garfinkel, R., Gopal, R. D., Venkatesan, R., \& Yin, F. (2010). Empirical analysis of the impact of recommender systems on sales. Journal of Management Information Systems, 27(2), 159-188.

Percy, L., \& Elliott, R. H. (2009). Strategic advertising management. Oxford University Press.

Rockendorf, D., (2011). Continental 2011 social media strategy. [Interview] (Personal communication, 14 June 2011).

Schiffman, L. G., \& Kanuk, L. L. (2000). Consumer behavior. Prentice Hall.

Schiffman, L. G., \& Wisenblit, J. H. (2015). Consumer behavior. Pearson.

Sekaran, U., \& Bougie, R. (2016). Research methods for business: A skill building approach. John Wiley and Sons.

Shavitt, S., Lowrey, P., \& Haefner, J. (1998). Public attitudes toward advertising: More favorable than you might think. Journal of Advertising Research, 38(4), 7-22.

Sun, T., Youn, S., Wu, G., \& Kuntaraporn, M. (2006). Online word-of-mouth (or mouse): An exploration of its antecedents and consequences. Journal of Computer Mediated Communication, 11(4), 1104-1127.

Tan, D. S., \& Piron, F. (2002). Advertising agencies and advertisers' perceptions of internet advertising. International Journal of Advertising, 21(3), 381-397. 
The Turkish Online Journal of Design, Art and Communication - TOJDAC

ISSN: 2146-5193, September 2018 Special Edition, p.721-728

Tassi, P. (2013). Facebook's advertising is starting to spiral out of control. http://www.forbes.com/ sites/insertcoin/2013/07/01/facebooks-advertisingis-starting-to-spiral-out-of-control/.

Taylor, D. G., Lewin, J. E., \& Strutton, D. (2011). Friends, fans, and followers: Do ads work on social networks? Journal of Advertising Research, 51(1), 258-275.

The Statistics Portal. (2017). Number of daily active Facebook users worldwide as of 2nd quarter 2017 (in millions). https://www.statista.com/statistics/346167/facebook-global-dau/.

Yang, H. (2013). Market mavens in social media: Examining young Chinese consumers' viral marketing attitude, eWOM motive, and behavior. Journal of Asia-Pacific Business, 14(2), 154-178.

Yin-Fah, B. C., Osman, S., \& Foon, Y. S. (2011). Simulation of sales promotions towards buying behavior among university students. International Journal of Marketing Studies, 3(3), 78-88. 